\section{Ks. Paweł Podeszwa}

Uniwersytet im. Adama Mickiewicza w Poznaniu podpaw@amu.edu.pl

ORCID: 0000-0002-4000-1660

DOI: http://dx.doi.org/10.12775/BPTh.2018.003

\section{Biblica}

et

Patristica

Thoruniensia

11 (2018) 1: 57-85

ISSN (print) 1689-5150

ISSN (online) 2450-7059

\title{
„Pan świeczników i gwiazd" (Ap 1,12-20) G. Bednarskiego - ilustracja czy interpretacja pierwszej wizji Apokalipsy Janowej?
}

\section{"The Lord of Candlestics and Stars" (Rev 1:12-20) by Grzegorz Bednarski - illustration or interpretation of first vision in The Book of Revelation?}

Streszczenie. W artykule omawiam jeden ze współczesnych przykładów oddziaływania Apokalipsy na sztukę, jakim jest cykl ilustracji polskiego artysty Grzegorza Bednarskiego do wybranych fragmentów ostatniej księgi biblijnej. Przedmiotem analizy jest pierwsza ilustracja cyklu, nosząca tytuł „Pan świeczników i gwiazd” (Ap 1,12-20), która przedstawia wstępną wizję, otwierającą Apokalipsę. Po omówieniu genezy powstania ilustracji G. Bednarskiego, krótkiej analizie tekstu biblijnego, stawiam pytanie zapowiedziane w tytule: czy praca polskiego artysty jest tylko bardziej lub mniej udaną ilustracją inspirującą się tekstem biblijnym czy stanowi jego interpretację nie tylko artystyczną, ale przed wszystkim teologiczną i przyczynia się do lepszego odczytania przesłania Apokalipsy? Przeprowadzone analizy pozwalają stwierdzić, że artysta pozostaje wierny przede wszystkim profetycznemu charakterowi Księgi Objawienia. Jego twórczość jest sztuką interpretacji oraz aktualizacji orędzia biblijnego. Artysta staje się egzegetą, który pędzlem maluje i wydobywa teologiczne przesłanie Księgi, staje się "głosem”, który „można i trzeba zobaczyć”, także po to, aby lepiej go zrozumieć. W ten sposób obraz komunikuje to, co wydaje się niewyobrażalne, a jednak ważne, konieczne i niezbędne.

Abstract. In this article I discuss one of contemporary examples of The Book of Revelation's influence to the art, which is the series of illustrations, created by Grzegorz Bednarski, to the chosen parts of the last Bible's book. "The Lord of Candlestics and Stars", first work of the series, showing the initial vision of the Apocalypse, was point of my analysis. After discussing the genesis Bednarski's illustrations and short review of the biblical text, I put a question presented in the title: Is the work of Polish artist is only a more or less successful drawing based on biblical text, or is rather theological interpretation, which enables to discover the real message of the Apocalypse? Analyses shows, that artist's work primarily remain faithful to the prophetic message of The Book 
of Revelation and is the way of interpretation and actualization biblical message. Artist became an exegetist, who extracts theological message from the Book. He is "the voice", which "can and should be seen" to have better understanding of it. In this way, Grzegorz Bednarski convey something unimaginable, but important, essential and necessary.

Słowa klucze: Apokalipsa; Chrystus zmartwychwstały; wizja wstępna; Bednarski; ilustracja; interpretacja.

Keywords: Apocalypse; Risen Lord; initial vision; Bednarski; illustration; interpretation.

Dla wielu ludzi, zarówno chrześcijan jak i wyznawców judaizmu, Biblia jest przede wszystkim słowem Boga wypowiedzianym do człowieka. Nie można jednak nigdy zapomnieć, że słowo to zostało usłyszane, a następnie spisane, w kontekście konkretnej kultury, w której powstawały poszczególne księgi biblijne. Autorzy Pisma Świętego korzystali obficie z ludzkich osiągnięć, przetwarzali je i przyjmowali za swoistego rodzaju tworzywo. Jak twierdzi ks. T. Jelonek „w tym sensie Biblia jest na wskroś ludzka, wyrasta z tego, co ludzkie, i karmi się osiągnięciami ludzkiej kultury, która odziewa słowo Boże w ludzką

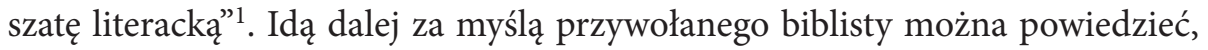
że „Biblia, która wyrosła $\mathrm{z}$ tego, co ludzkie, i zaciągnęła swoisty dług wobec kultury człowieka, spłaca ten dług, stając się z kolei tworzywem dla ludzkiej działalności kulturowej. To oddziaływanie najbardziej uwidacznia się w dziedzinie literatury i sztuk plastycznych, ale jego zakres okazuje się o wiele szerszy”2. W ten sposób Biblia stała się i pozostaje „wielkim kodem kulturowym”. W adhortacji apostolskiej Verbum Domini papież Benedykt XVI przypomniał, że „Słowo Boże na przestrzeni wieków inspirowało różne kultury, czego owocem były podstawowe wartości moralne, znakomite formy sztuki i wzorcowe style życia”", a „związek między słowem Bożym i kulturą znalazł wyraz w dziełach z różnych dziedzin, zwłaszcza w świecie sztuki" 5 . Z tego też powodu Biblia od dawna aż po dzień dzisiejszy inspiruje zwłaszcza artystów, którzy poprzez swoje dzieła nie tylko ilustrują tekst biblijny, ale starają się go interpretować

\footnotetext{
T. Jelonek, Biblia, s. 111.

Ibidem.

3 Benedykt XVI, Verbum, nr 110, s. 115.

4 Ibidem, nr 109, s. 114.

5 Ibidem, nr 112, s. 115.
} 
i aktualizować 6 , przyczyniając się w ten sposób do lepszego zrozumienia samego tekstu, ale przede wszystkim jego przesłania.

Wśród ksiąg biblijnych, które często są natchnieniem dla twórców kultury, ważne miejsce Apokalipsa Janowa, zamykająca kanon Nowego Testamentu ${ }^{7}$. Księga to niezwykła, tajemnicza, nieustannie pobudzająca wyobraźnię człowieka. Zdaniem kard. G. Ravasiego,

kiedy otwieramy tę księgę, doświadczamy pewnego przyciągania, a zarazem zawrotu głowy. Jest to tekst wyżłobiony przez krew historii, lecz także działo kontemplacji, zatopione w aureoli światła, z którego na końcu wyłania się miasto doskonałe i idealne, gdzie nie ma już płaczu, gdzie śmierć nie ma prawa bytu i gdzie rozpala się transcendentna świetlistość (rozdz. 21-22). Tekst ten wprawia w zdumienie również pod względem stylistycznym: jest barbarzyński i kreatywny, śmiały i wyważony, wierny schematom (słynne są liczne układy składające się z siedmiu elementów), a przecież nigdy niemechaniczny w ich stosowaniu; dziki, a jednak obdarzony arystokratyczną elegancją, popularny, a zarazem wyszukany, gotów „rzucać wyzwania elementarnym prawom gramatyki lub syntaksy..., dzieło autora, który myślał po hebrajsku lub aramejsku, a pisał po grecku" (Robert H. Charles), wszelako uroczysty i niepowtarzalny. Ta księga jest owocem niepohamowanej kreatywności, zdolnej tworzyć sceny oślepiające światłem, które zdaje się wyprzedzać malarza Boscha lub pisarza Kafkę, albo reżyserów Bergmana i Bunuela. Równocześnie jest to dzieło teologiczne ze ścisłe określonymi paradygmatami myśli, tak iż prezentuje jedną z najbogatszych chrystologii w całym Nowym Testamencie. Wystarczy tylko przypatrzeć się uroczystemu portretowi Chrystusa zmartwychwstałego na początku dzieła $(1,12-10)^{8}$.

Apokalipsa, choć potocznie kojarzona często jako księga, zawierająca złowieszcze przepowiednie, odnoszące się zwłaszcza do końca świata, w rzeczywistości pozostaje księgą nadziei i pocieszenia, „księgą teraźniejszości i przyszłości, walki i nadziei, nasienia i drzewa, Jerozolimy historycznej goszczącej także okrutny Babilon oraz Jerozolimy nowej i świętej, lęku i radości, sądu i chwały”. Tak niezwykły utwór poetycki wraz ze swoimi wizjami i symbolami w naturalny sposób inspiruje także współczesną kulturę i sztukę. Jest to tym bardziej ciekawe, że zgodnie $\mathrm{z}$ tradycyjnym podziałem, zaproponowanym przez św. Tomasza z Akwinu, wizje mogą mieć charakter wyobrażeniowy, to znaczy taki, który oddziałuje na wyobraźnie wizjonera lub charakter intelektualny albo

6 Zob. R. Knapiński, Egzegeza, s. 45-75.

7 Zob. W. Popielewski, Od „Siódmej pieczęci”, s. 249-265.

8 G. Ravasi, Apokalipsa, s. 6-7.

9 Ibidem, s. 15. 
symboliczny, czyli taki, który nie ma zamiaru oddziaływać na wyobraźnię, ale wyraża jedynie treść duchową. Innymi słowy odbiorca ma pytać przede wszystkim, co wizja znaczy, jaka jest jej treść, zamiast próbować ją sobie wyobrażaćio. I nawet jeśli faktycznie wiele wizji Apokalipsy mają taki charakter intelektualny i symboliczny, to jednak wpływają na wyobraźnię człowieka, zwłaszcza artysty, który „odmalowując” słowo, pozwala czytelnikowi „ujrzeć głos” (Ap 1,12), aby lepiej go pojąć i zrozumieć przesłanie w nim wyrażone.

$\mathrm{W}$ niniejszym artykule chciałbym zaprezentować jeden $\mathrm{z}$ wymownych współczesnych przykładów oddziaływania Apokalipsy na sztukę, jakim jest cykl ilustracji polskiego artysty Grzegorza Bednarskiego do wybranych fragmentów ostatniej księgi biblijnej. Przedmiotem analizy będzie pierwsza ilustracja cyklu, nosząca tytuł „Pan świeczników i gwiazd” (Ap 1,12-20), która przedstawia wstępną wizję, otwierającą Apokalipsę. Po omówieniu genezy powstania ilustracji G. Bednarskiego, krótkiej analizie tekstu biblijnego, spróbujemy odpowiedzieć na pytanie postawione w tytule: czy praca polskiego artysty jest tylko bardziej lub mniej udaną ilustracją inspirującą się tekstem biblijnym czy stanowi jego interpretację nie tylko artystyczną, ale przed wszystkim teologiczną i przyczynia się do lepszego odczytania przesłania Apokalipsy.

\section{Geneza przedsięwzięcia}

Po bardzo udanym bibliofilskim wydaniu „Pisma Świętego Nowego i Starego Testamentu”, które ukazało się nakładem Drukarni i Księgarni św. Wojciecha w Poznaniu w 2006 r. ${ }^{11}$, ta sama oficyna wydawnicza przygotowała publikację Apokalipsy świętego Jana Apostoła, w nowym przekładzie z języka greckiego poznańskiego biblisty ks. prof. Jana Kantego Pytla ${ }^{12}$. Do współpracy zaproszono artystę Grzegorza Bednarskiego ${ }^{13}$. Wybór tego artysty Wydawca kon-

10 Zob. P. Ostański, Objawienie, s. 28. Zdaniem Autora, „artyści, którzy w swoich dziełach próbowali przedstawić wizje Apokalipsy, nie rozumieli podstawowego założenia stylu apokaliptycznego, a wydawcy, ilustrując takimi obrazami Księgę Apokalipsy, robili czytelnikowi najgorszą przysługę. Każdy szczegół wizji apokaliptycznych trzeba traktować symbolicznie i zaniechać prób wyobrażania go sobie, ale jedynie pytać o treść, jaką niesie”.

11 P. Podeszwa, Od inspiracji do interpretacji, s. 159-171.

12 Apokalipsa.

13 Grzegorz Bednarski urodził się w 1954 roku w Bydgoszczy. W latach 1975-1980 kształcił się na Wydziale Malarstwa Akademii Sztuk Pięknych w Krakowie. Dyplom uzyskał u prof. J. Szancenbacha. Od 1980 roku rozpoczął pracę pedagogiczną na macierzystej uczelni. Od roku 1998 kieruje własną pracownią malarstwa w ASP w Krakowie. W latach 1981-1989 brał aktywny udział w ruchu kultury niezależnej, tworząc ekspresyjne prace 
sultował z prof. Renatą Rogozińską z Uniwersytetu Artystycznego w Poznaniu, która w jednym ze swoich artykułów tak pisze: „Rozpocznę od osobistego wspomnienia. Kiedy wiosną 2006 roku zwróciło się do mnie Wydawnictwo św. Wojciecha z prośbą o radę, któremu z naszych artystów można by powierzyć wykonanie ilustracji do Apokalipsy św. Jana, odpowiedziałam bez chwili wahania: oczywiście Grzegorzowi Bednarskiemu. Jego kandydatura wydawała mi się wręcz idealna. Przemawiał za nią charakter jego całej dotychczasowej twórczości, w której już zresztą wcześniej pojawiały się inspiracje tą ezoteryczną księgą. Miałam jeszcze świeżo w pamięci wizjonerskie, potężne nie tylko formatem płótno Święty Jan na wyspie Patmos zjada książeczkę Wszechrzeczy podana przez Anioła (2000-2003) z cyklu Personifikacje, eksponowane w „Galerii u Jezuitów” w Poznaniu w 2004 roku”" ${ }^{14}$. Zdaniem autorki jest wiele wspólnego między przesłaniem Apokalipsy, którą nazywa "thrillerem metafizycznym”, a dziełami malarskimi Bednarskiego „skupionego na skandalu istnienia, przeżywanym i unaocznianym (jak na ekspresjonistę przystało) w sposób przejaskrawiony, niewolny od patosu i egzaltacji”"15. Jego dzieła

nie są jednak osadzone jedynie w getcie doczesności, pojmowanej płasko, materialistycznie. Przeciwnie, pozostają na swój własny sposób otwarte na perspektywę eschatologiczną, ujawniają nadprzyrodzony status istnienia człowieka, pojmowany, zgodnie ze światopoglądem twórcy, w duchu chrześcijaństwa. Są wręcz wyrazem rebelii artysty, manifestującego niezgodę zarówno na odarcie świata $\mathrm{z}$ wyższego, sakralnego sensu, jak i na jego nostalgiczną idealizację, tuszującą poczucie lęku, bezradności, absurdu. Stąd niesłychanie istotnym źródłem inspiracji była dlań zawsze literatura religijna: Biblia, apokryfy oraz żywoty świętych, w których jest miejsce nie tylko na nadzieję, miłość, piękno, ale także na świat pełen krwi

poruszające problematykę egzystencjalno-metafizyczną. Artysta zaliczany jest do tzw. figuracji krakowskiej. Na początku lat 90. zaczął malować jak sam powiedział: „zwyczajne małe obrazki”, oszczędne przedstawienia prostych przedmiotów, ujawniające m.in. fascynacje czystym kolorem i światłem. Przedmioty - symbole, jak jajko czy czaszka, zestawione z ubogimi sprzętami życia codziennego zbliżają nas do tajemnic egzystencjalnych. Artysta w swoich pracach rysunkowych inspirował się dziełami literackimi takich autorów jak: Dante, Stanisław Czycz, Stanisław Świątek czy Krzysztof Lipka. Obok rysunków piórem i tuszem artysta posługuje się tłustym pastelem oraz wykorzystuje technikę kolażu. Twórczość artysty koncentruje się głównie wokół cykli malarskich: Wielki metafizyk, 1981; Ni mas ni menos, 1984; Hedonista maluje Ukrzyżowanie, 1998-2002; Personifikacje; 1998-2002; Popielec, 2001-2004) oraz rysunkowych (Dom misteriów, 1990; Bajka paryska-śmiej się dziadku, 1994; Czy czyta pani Czycza czy Czycza pani zna, 1996-1999; Inferno, 1993-2000, zob. Nota biograficzna.

14 R. Rogozińska, Apokalipsa, s. 95.

15 Ibidem, s. 96. 
i ran. Te literackie inspiracje traktuje Bednarski często z dezynwolturą, w sposób nad wyraz osobisty i pełen fantazji, lecz równocześnie z głębokim namysłem i poszanowaniem dla ich nieprzemijających wartości ${ }^{16}$.

Natomiast tłumacz tekstu ks. prof. Pytel w jednym ze swoich wywiadów wspomina:

Inicjatywa nowego przekładu wyszła przed kilku laty od księdza Bogdana Reformata, który był wówczas dyrektorem Drukarni i Księgarni św. Wojciecha. On w szczególny sposób ukochał księgę Apokalipsy. Początkowo zaproponował jej przekład ks. prof. Marianowi Wolniewiczowi, ale najpierw zwłoka, a później śmierć sprawiły, że ów zamiar nie został zrealizowany. Później zwrócił się z podobną prośbą do mnie. [...] Pracowałem mozolnie przez pół roku, natomiast oryginalne ilustracje wykonał artysta malarz Grzegorz Bednarski. Początkowo zgodził się na sześć malowideł, ale ja zaproponowałem trzynaście tematycznie związanych z Apokalipsą ${ }^{17}$.

A na pytanie dziennikarza, czy owe ilustracje spełniły oczekiwania tłumacza, ten odpowiedział:

Kiedy je ujrzałem, byłem zachwycony, bo dostrzegłem podobieństwo do witraży Marca Chagalla, które widziałem w kościele w Moguncji. Uczestnicy niedawnej konferencji prasowej uznali je za szokujące i wstrząsające. A mnie najbardziej urzekła ilustracja Niewiasty otrzymującej skrzydła orle, aby odlecieć od Smoka na pustynię, a także dwie Bestie, które razem ze Smokiem tworzą triadę diaboliczną ${ }^{18}$.

Owocem pracy G. Bednarskiego, który „na propozycję Wydawnictwa zareagował wręcz entuzjastycznie" ${ }^{19}$, jest zatem trzynaście ilustracji inspirowanych tekstem biblijnym. Wymieniam je w kolejności i z tytułami, które znajdują się w wydaniu Apokalipsy:

1) Pan świeczników i gwiazd (Ap 1,12-20)

2) Bóg przekazuje Barankowi zapieczętowaną księgę (Ap 5,5-7)

3) Zabici świadkowie Słowa Bożego (Ap 6,9-11)

4) Aniołowie powściągają huragany przed naznaczeniem sług Bożych pieczęcią (Ap 7,1-4)

5) Nadprzyrodzona moc dwóch Świadków (Ap 11,3-5)

16 Ibidem, s. 96-97.

17 M. Gryczyński, Zrozumieć przesłanie.

18 Ibidem.

19 R. Rogozińska, Apokalipsa, s. 97. 
6) Niewiasta otrzymuje skrzydła orle, aby móc odlecieć od Smoka (Ap 12,1-18)

7) Besta z morza - symbol przemocy (Ap 13,1-8)

8) Baranek na górze Syjon, wysławiany pieśnią nową (Ap 14,1-5)

9) Dzień gniewu Bożego (Ap 14,14-19)

10) Wielka Nierządnica $z$ pucharem obrzydliwości (Ap 17,1-18)

11) Zwycięski Jeździec - Król królów i Pan panów (Ap 19,11-18)

12) Przemija świat zła - nadchodzi Nowe Jeruzalem (Ap 21,1-8)

13) Wołanie o powtórne przyjście Pana (Ap 22,6-21) ${ }^{20}$.

Z publikacji dowiadujemy się, że ilustracje Grzegorza Bednarskiego do tekstu zostały wykonane w 2007 r., techniką rysunku, pastelu oraz wycinanki. Format oryginałów to $100 \times 70 \mathrm{~cm}$ oraz $70 \times 50 \mathrm{~cm}^{21}$.

W artykule zamierzam szczegółowo omówić pierwszą ilustrację, zatytułowaną „Pan świeczników i gwiazd” (Ap 1,12-20)22, inspirującą się wstępną wizją Apokalipsy, której bohaterem jest zmartwychwstały Chrystus. Dlaczego właśnie ta wizja? Ponieważ otwiera ona Księgę i oferuje czytelników od samego początku najważniejsze klucze hermeneutyczne, które trzeba uwzględniać dla zrozumienia Księgi Objawienia: kontekst liturgiczny (wspólnota zgromadzona na liturgii, która celebruje obecnego chwalebnego Chrystusa), medytacja Pism Starego Testamentu w kluczu chrystologicznym oraz symbolizm jako podstawowe narzędzie komunikacji, gdzie czas jest rozumiany specyficznie: przeszłość, teraźniejszość i przyszłość wzajemnie się przenikają ${ }^{23}$. Ponadto jest ona zaliczana do wizji intelektualnych, a struktura symbolizmu w niej występującego bywa określana jako „nieciągła” lub jako „kolumna symboliczna”, co znacznie utrudnia jej wyobrażenie ${ }^{24}$. Stawiamy zatem pytanie: czy ilustracja za-

20 Apokalipsa, s. 69-95. Ilustracje Bednarskiego można także zobaczyć na stronie internetowej: http://www.wroclaw.biblista.pl/index.php?option=com_content\&view $=$ article\&id=261:obraz-i-apokalipsa- $w$-jana\&catid=32:biblia-i-sztuka, [dostęp: 02.10.2017].

21 Apokalipsa, s. 97.

22 Ibidem, s. 70-71.

23 Zob. D. Kotecki, Kryteria, s. 16. Autor pisze jeszcze o czwartym kryterium, a mianowicie o konieczności uwzględniania środowiska („Sitz im Leben”), w którym żyje wspólnota.

24 Zdaniem U. Vanni, L’Apocalisse, s. 55-58 można w Apokalipsie wyróżnić trzy podstawowe poziomy struktur symbolicznych. Pierwsza to struktura kontynuacyjna („,una struttura coerente e continua"), gdzie wystarczy interpretować kolejno symbol po symbolu, otrzymując spójny i linearny obraz, który pozwala uchwycić całość obecnego przesłania $(6,1-8)$. Drugi rodzaj struktury symbolicznej to struktura nieciągła („una struttura discon- 
proponowana przez G. Bednarskiego do pierwszej wizji Apokalipsy jest tylko wizualizacją tekstu biblijnego (wierną lub nie, bardziej lub mniej udaną), czy raczej mamy do czynienia $z$ interpretacją (od inspiracji do interpretacji) tekstu biblijnego? Jeśli jest to interpretacja, to jakich aspektów dotyczy i czy przyczynia się do lepszego (zgodnego z intencją Autora natchnionego) rozumienia tekstu? Innymi słowy stawiamy pytanie; czy mamy do czynienia z „kalką” tekstu biblijnego, czy raczej z artystycznym komentarzem, interpretacją, trawestacją tekstu? Spoglądam na ten obraz z perspektywy biblisty i teologa, ocenę artystycznych środków wyrazów pozostawiam specjalistom w tej dziedzinie.

\section{Pan świeczników i gwiazd (Ap 1,12-20)}

\subsection{Tekst biblijny}

Zacznij od lektury tego fragmentu w przekładzie ks. Pytla:

12 I odwróciłem się, aby ujrzeć głos, który do mnie mówił. Odwróciwszy się, zobaczyłem siedem złotych świeczników. $13 \mathrm{~W}$ pośrodku zaś siedmiu świeczników ujrzałem kogoś podobnego do Syna Człowieczego, przyobleczonego w szatę sięgającą do stóp, przepasanego na piersi złotą szarfą. 14 Głowa Jego i włosy były niczym wełna śnieżnobiała. Oczy Jego jak płomień ognia, 15 Jego nogi jakby z drogocennego kruszcu w piecu rozżarzonego, a głos Jego jak szum spiętrzonej wody. $16 \mathrm{~W}$ swojej prawicy miał siedem gwiazd. Z Jego ust wychodził miecz ostry obosieczny, a Jego oblicze jaśniało jak słońce w swej mocy. 17 Kiedy Go ujrzałem, padłem do Jego nóg jak martwy, a On położył na mnie swą prawicę i rzekł: „Nie lękaj się! Ja jestem Pierwszy i Ostatni, 18 i Żyjący na wieki wieków i mam klucze Śmierci i Otchłani. 19 Napisz więc, co widziałeś i co jest, i co potem się stanie. 20 Poznaj tajemnicę siedmiu gwiazd, które widziałeś w mojej prawicy, i siedmiu

tinua”), w której nie da się zinterpretować wszystkich elementów symbolicznych w jednym spójnym łańcuchu znaczeniowym. Należy najpierw dekodyfikować poszczególne symbole, aby potem dokonać próby syntezy poszczególnych treści, bez harmonizowania całości obrazu symbolicznego, który nawet po odczytaniu poszczególnych elementów pozostaje niemożliwy do logicznego wyobrażenia całości obrazu $(1,9-20 ; 12,1-6)$. Trzecim typem struktury symbolicznej jest struktura obfitująca („una struttura ridondante”), której charakterystycznym elementem jest hiperboliczne wyakcentowanie jakiegoś nawet pojedynczego symbolu, co służy wywołaniu w słuchaczu/czytelniku Księgi silnego wrażenia (9,16; 14,20; 21,19-20). L. Pedroli, Dal fidanzamento alla nuzialità, s. 114-115, powołując się na opracowanie U. Vanniego, określa poszczególne poziomy struktur symbolicznych obecnych w Apokalipsie jako: „una costruzione continua”, „una colonna simbolica”, „una struttura ridondante”, zob. także P. Podeszwa, Paschalna pamięć, s. 338-339. 
złotych świeczników: siedem gwiazd to aniołowie siedmiu Kościołów, a siedem świeczników to siedem Kościołów ${ }^{25}$.

\subsection{Kontekst literacki}

Jak zostało to już zasygnalizowane wcześniej powyższy tekst stanowi wizję wprowadzającą Apokalipsy ${ }^{26}$. Poprzedzony jest bezpośrednio prologiem $(1,1-3)$, pozdrowieniem o charakterze liturgicznym $(1,4-8)$ oraz autoprezentacją Autora wraz z wyjaśnieniem powodów napisania Księgi $(1,9-11)$. Jan $(1,9)$ miał widzenia (dosł. „znalazł się w Duchu”27) na wyspie Patmos $(1,9)$ w „Dzień Pański” $(1,10)$, to znaczy w niedzielę, co potwierdza liturgiczny charakter analizowanego tekstu. Odnosi się bowiem do wspólnoty zebranej na celebrowaniu Eucharystii w dzień zmartwychwstałego Pana. Zmartwychwstały Chrystus ukazuje się zatem w liturgicznym zebraniu wspólnoty Kościoła. Podczas tego widzenia objawiającego Autor trzymuje polecenia spisania wszystkiego, co widzi oraz posłania siedmiu Kościołom (do Efezu, Smyrny, Pergamonu, Tiatyry, Sard, Filadelfii, Laodycei), które reprezentują całą prowincję rzymską, Azję Prokonsularną, a w języku symbolizmu arytmetycznego Księgi oznaczają cały Kościół powszechny każdego czasu ${ }^{28}$.

Pierwsza część wizji dokonuje się za plecami Jana (1,9-11). Odczuwa on pragnienie zobaczenia głosu, który mówi do niego. Dlatego odwraca się, aby "zobaczyć głos” (1,12a). W wyrażeniu tym mamy połączone dwa aspekty: „widzieć" i „głos"29. Pierwsze znaczenie może być następujące: Jan usłyszawszy za sobą głos, chce teraz zobaczyć osobę, która do niego mówi ${ }^{30}$. Skoro mówi sam Bóg, to Jego głos (słowo) „pociąga” Jana ku sobie w kierunku transcendencji. W literaturze judaistycznej "głos” jest identyfikowany ze słowem Bożym, a nawet samym Bogiem, zastępując imię Boże ${ }^{31}$. Jan odczuwa pragnienie, a może nawet ciekawość „zobaczenia” Tego, z kim rozmawia i tego, co słyszy. Tekst nie

25 Apokalipsa, s. 19. Autor przekładu nadaje temu fragmentowi tytuł: „Pan świeczników i gwiazd".

26 Zaproponowana analiza wizji zaczerpnięta z P. Podeszwa, Paschalna pamięć, s. 205-225; zob. także D. Kotecki, Jezus, s. 136-204.

27 Na temat tego wyrażenia, zob. D. Kotecki, Duch Święty, s. 41-52; 289-297.

28 Zob. P. Ostański, Objawienie, s. 79.

29 Podobne wyrażenia występują w Starym Testamencie, zob. D.E. Aune, Revelation, s. 87.

30 Zdaniem J.H. Charlesworth'a, The Jewish Roots, s. 19-41, chodzi tutaj o niebiański byt hipostatyczny. E. Lupieri, L’Apocalisse, s. 116, mówi w tym miejscu o aniele.

31 Zob. D.E. Aune, Revelation, s. 88. 
precyzuje jednoznacznie kto jest podmiotem mówiącym, co stanowi celowy zabieg Autora, „aby wprowadzić słuchaczy w kontakt z tajemnicą, która dotyczy samego Boga, jest objawieniem prawdy o Nim"32.

\subsection{Symboliczne elementy wizji i ich znaczenie teologiczne}

W 1,12b rozpoczyna się właściwa wizja. Jan widzi najpierw „siedem złotych świeczników”, a pośrodku nich "kogoś podobnego do Syna Człowieczego” $(1,13)$. Świeczniki nawiązują do Wj 25,31. Chodzi o świeczniki ze szczerego złota, będące na wyposażeniu Przybytku, a zatem mamy do czynienia z przedmiotem liturgicznym ściśle związanym $\mathrm{z}$ kultem ${ }^{33}$. Według interpretacji danej w 1,20 siedem świeczników oznacza siedem Kościołów. Biorąc pod uwagę symbolizm liczby siedem oraz świeczników, chodzi o wspólnotę Kościoła widzianą w swej pełni, która gromadzi się na liturgii i w ten sposób wchodzi w kontakt $\mathrm{z}$ transcendencją. Pośród siedmiu świeczników Jan widzi zmartwychwstałego Jezusa, który został opisany przy pomocy biblijnych obrazów zaczerpniętych z elementów proroctw Daniela $(7,9.13)$ oraz Ezechiela $(1,26 ; 9,2.11 ; 43,2)$ : jest „podobny do Syna Człowieczego” ${ }^{4}$, co oznacza, że „Ten, ktoś wyglądał na Syna Człowieczego, ale był więcej niż człowiek" ${ }^{35}$. Pojawia się między świecznikami, które wyznaczają idealną przestrzeń (Kościół i liturgię) obecności i aktywności zmartwychwstałego Pana ${ }^{36}$. Być może mamy tutaj także nawiązanie do obecności Boga pośród swego ludu (Kpł 26,12). „Podobny do Syna Człowieczego” jest zatem „widziany w roli, jaka w Starym Testamencie była przypisywana Bogu Izraela” ${ }^{37}$. Tajemnicza postać znajduje się „pośrodku” świeczników, to jest ich centrum. Jak zauważa ks. Kotecki, „świeczniki musiały uformować krąg, którego punktem centralnym był Chrystus. On jest przedstawiony w jednakowej odległości do wszystkich świeczników, tj. Kościołów (por. 1,20). Jest On ukazany jako najważniejsza osoba w środowisku Kościoła. On jest punktem odniesienia ich życia. Cały ten obraz może wyrażać relację tej postaci do poszczególnych Kościołów. On traktuje je z taką samą atencją, czy miłością"38.

32 D. Kotecki, Jezus, s. 144.

33 Zob. ibidem, s. 145-147.

34 Szeroko na temat Syna Człowieczego, zob. F. Sieg, „Podobny do Syna Człowieczego”, s. 251-255.

35 A. Jankowski, Syn Człowieczy, s. 40.

36 Zob. U. Vanni, L’Apocalisse, s. 125, także D. Kotecki, Duch Święty, s. 203.

37 D. Kotecki, Jezus, s. 147.

38 Ibidem, s. 150. 
Zmartwychwstały ubrany jest w długą szatę „sięgającą aż do stóp” $(1,13)$, która symbolicznie oznacza Jego godność arcykapłańską ${ }^{39}$. Szata nie jest symbolem czegoś zewnętrznego, lecz wręcz czegoś wewnętrznego, określonej postawy tego, kto ją nosi ${ }^{40}$. Mamy zatem pierwszą prezentację Chrystusa zmartwychwstałego w Apokalipsie jako arcykapłana ${ }^{41}$, przedstawionego $\mathrm{w}$ relacji kapłańskiej w stosunku do wizjonera i wspólnoty Kościoła ${ }^{42}$. Interpretację kapłańską szaty Jezusa potwierdza jeszcze jeden element, należący do opisanego stroju Syna Człowieczego, a mianowicie złoty pas, którym jest przepasany na piersiach. Zasługuje on na uwagę z dwóch powodów. Najpierw z tego, że jest on złoty. Jest to charakterystyczny kolor, który w Apokalipsie pojawia się często w kontekście liturgicznym, choć nie można także wykluczyć interpretacji królewskiej (por. 1 Mch 10,89) ${ }^{43}$. Kolor ten zatem może wskazywać także na przynależność „podobnego do Syna Człowieczego” do transcendencji ${ }^{44}$. Sposób przepasania złotej szarfy wskazuje na wyjątkowość Syna Człowieczego: pas nie jest na biodrach, ale znacznie wyżej, dosłownie „na piersiach" ${ }^{45}$. Zatem Jezus jest przedstawiony jako arcykapłan, ale jego funkcja kapłańska jest inna, wyjątkowa w porównaniu z funkcjami kapłańskim, jakie znamy ze Starego Testamentu, choć tekst nie precyzuje jeszcze, na czym ta wyjątkowość Chrystusa polega.

Kolejne elementy wizji Syna Człowieczego wyraźnie wskazują na Jego kontakt z transcendencją. „Głowa Jego i włosy były niczym wełna śnieżnobiała. Oczy Jego jak płomień ognia, Jego nogi jakby z drogocennego kruszcu w piecu rozżarzonego, a głos Jego jak szum spiętrzonej wody" (1,14-15). W wizji Apokalipsy Syn Człowieczy jest zatem opisany w sposób charakterystyczny dla Boga, przy czym Autor emfatycznie podkreśla kolor biały, zarówno głowy, jak i włosów, rozdzielając wyraźnie te dwa elementy. W sposób symboliczny została wyrażona jakby podwójna ilość koloru białego, który jest porównany do „białej wełny” i „śniegu”. Akcent położony na kolor biały ma swoje uzasadnienie, ponieważ w Apokalipsie symbolicznie oznacza wymiar transcendentny zrealizowany przez zmartwychwstanie Chrystusa. W tym „nagromadze-

Szczegółowo na ten temat, zob. P. Podeszwa, Jezus, s. 202-207.

Zob. S. Gądecki, Wstęp, s. 173.

Zob. T. Jelonek, Biblijna teologia, s. 165-166.

Zob. M.-L. Rigato, Giovanni: l'enigma, s. 316.

Zob. G.K. Beale, The Book, s. 209.

Zob. D. Kotecki, Jezus, s. 156.

Zob. U. Vanni, L'Apocalisse, s. 127-128.
} 
niu" koloru białego możemy także widzieć aluzję do przemienienia Jezusa ${ }^{46}$, podczas którego „odzienie Jezusa stało się białe” (Mt 17,2; Mk 9,3; Łk 9,29). Biel szat Jezusa wskazuje na Jego transcendencję, a w kontekście opowiadania o przemienieniu jest też zapowiedzią Jego zmartwychwstania ${ }^{47}$. Ponadto biały kolor włosów może wskazywać na Jego odwieczność, wieczne trwanie ${ }^{48}$, nieskończoność, czystość i bezgrzeszność, które są atrybutami samego Boga ${ }^{49}$.

Zmartwychwstały ma „oczy jak płomień ognia”. Widoczna jest tu aluzja do Dn 10,6, gdzie mowa jest o „oczach jak pochodnie ognia”. W Apokalipsie kolejny raz następuje swoistego rodzaju intensyfikacja obrazu. Nie są to już „pochodnie ognia”, ale „płomień ognia”, czysty, płonący ogień. Oczy Syna Człowieczego oznaczają umiejętność przenikania rzeczywistości, Jego Boskiej wszechwiedzy, Jego zdolności „widzenia” sytuacji Kościoła. To spojrzenie niesie ze sobą "moc ognia”, który oczyszcza, udoskonala, bezwzględnie niszczy i pali to wszystko, co nie jest zgodne z Jego wolą i oczekiwanym sposobem egzystencji wspólnoty wierzących.

Stopy Syna Człowieczego są , jak drogocenny kruszec rozżarzony w piecu”. Stopy z metalu są symbolem stałości i mocy Chrystusa, w odróżnieniu od nóg olbrzyma ze snu Nabuchodonozora, którego stopy częściowo były z żelaza, częściowo z gliny (Dn 2,34.41-42), co zapowiadało upadek i kruchość. Być może mamy tutaj także nawiązanie do Dn 7,10, gdzie zostaje przedstawiona „rzeka ognia”, która wypływa spod tronu Boga. To nagromadzenie ognia (oczy i stopy), które wskazuje na jego obecność w całym ciele „podobnego do Syna Człowieczego" upodabnia Go jednoznacznie do Boga Izraela ${ }^{50}$.

Wizja inauguracyjna Syna Człowieczego jest także wstępem do pierwszej części Apokalipsy, którą stanowią Listy do siedmiu Kościołów (2,1-3,22). W jednym $\mathrm{z}$ nich, w Liście do Kościoła w Tiatyrze (2,18-29), powracają oba elementy wizji Syna Człowieczego. W 2,18 Chrystus w autoprezentacji przedstawia się w następujący sposób: „To mówi Syn Boży, którego oczy są jak płomień ognia, a nogi podobne do drogocennego metalu". Porównując te dwa

46 Zdaniem G. Segalli, La memoria, s. 122, elementem wspólnym obu tekstów jest też wezwanie „nie lękaj się” w 1,17 oraz „wstańcie, nie lękajcie się” w Mt 17,7.

47 C. Doglio, Il Primogenito, s. 181-182. Na temat dwóch możliwości interpretacji wydarzenia przemienienia w perspektywie mistagogicznej (wschodniej) oraz pedagogicznej (zachodniej), która podkreślała, że przemienienie należy rozumieć jako zapowiedź zmartwychwstania, widząc w tym wydarzeniu umocnienie wiary Apostołów wobec czekającego ich skandalu krzyża, zob. A. Malina, Mistagogiczny, s. 170-181.

\footnotetext{
48 Zob. G. Biguzzi, Apocalisse, s. 84.

49 Zob. P. Ostański, Objawienie, s. 81.

50 Zob. D. Kotecki, Jezus, s. 164-165.
} 
teksty widzimy paralelizm między Synem Człowieczym z 1,13 a Synem Bożym z 2,18. Mamy zatem jednoznaczną identyfikację zmartwychwstałego Syna Człowieczego - nowego Adama z Synem Bożym.

Także kolejny element zaczerpnięty z symbolizmu kosmicznego potwierdza powyższą identyfikację. Odnosi się on do głosu Syna Człowieczego, który jest „jak szum spiętrzonej wody”. Podobnie i ten symbol kolejny raz odsyła do proroctwa Daniela, bo w przywoływanym już tekście 10,6 czytamy, że „dźwięk jego głosu - jak krzyk tłumów”. Niewątpliwie jest to punkt wyjścia dla symbolicznego znaczenia w Apokalipsie, bo już u Daniela odnosi się do bytu transcendentnego. Dodatkowo ten element symboliczny zostaje zinterpretowany poprzez nawiązanie do proroka Ezechiela ${ }^{51}$. Podczas teofanii prorok widzi skrzydła istot żywych, a szum ich skrzydeł „był jak szum wielkich wód, jak głos Wszechmogącego" $(1,24)$. Jeszcze bardziej wymownym tekstem jest opis powrotu Boga do świątyni w 43,2: „A oto chwała Boga Izraela przybyła od wschodu. Jej szum był jak szum wielkich wód”. Dzięki tym odniesieniom starotestamentalnym Autor Apokalipsy całkowicie umieszcza Syna Człowieczego w sferze transcendencji oraz przypisuje Mu atrybut, który przynależał „chwale Boga Izraela”, a zatem samemu Bogu ${ }^{52}$. Wcześniej głos Syna Człowieczego został już określony jako „głos potężny jak dźwięk trąby” $(1,10)$. Wizjoner obraca się, „aby zobaczyć głos” $(1,12)$. Jest to zatem głos, który nie tylko zapowiada obecność Boga, ale ją realizuje i określa; cała moc Boża wyraża się w "głosie”, który jest symbolem słowa Bożego. W ten sposób wspólnota Kościoła zostaje przygotowana stopniowo do słuchania i przyjęcia „głosu” Syna Człowieczego, który jest słowem Boga, skierowanym do siedmiu Kościołów Azji, to znaczy całego Kościoła Chrystusowego. Jest to głos mocy Boga, objawiający Jego chwałę i uobecniający Zmartwychwstałego we wspólnocie chrześcijan.

Jeszcze bardziej aspekt bliskości Syna Człowieczego i wspólnoty zostaje podkreślony przez kolejny element symboliczny: „w swojej prawicy miał siedem gwiazd” $(1,16)$. Według symbolizmu antropologicznego „mieć w prawym ręku” oznacza trzymać w sposób pewny, stały, z całym zaangażowaniem, także mieć władzę nad tym, co się trzyma i jednocześnie troszczyć się o tę rzeczywistość. Jezus „ma siedem gwiazd”. Oba elementy należą do typowego dla Apokalipsy symbolizmu kosmicznego i arytmetycznego. Jak wyjaśnia sam Autor w 1,20 „siedem gwiazd to aniołowie siedmiu Kościołów”. Chociaż wyrażenie pozostaje dość enigmatyczne, bo może odnosić się do aniołów stróżów danych 
wspólnot lub przełożonych - biskupów poszczególnych Kościołów ${ }^{53}$, to jednak porównanie do „gwiazd” wskazuje na pewien sposób przynależności do transcendencji Boga, na całkowite pozostawanie w ręku zmartwychwstałego Pana - Pośrednika między Bogiem a Kościołem.

Chrystus komunikuje się ze wspólnotą poprzez głos - słowo Boże, które teraz zostaje określone jako „ostry, obosieczny miecz”, który „wychodził z ust Jego" $(1,16)$. Być może inspiracją do tego elementu symbolicznego było proroctwo Izajasza, gdzie czytamy, że „moje usta uczynił jakby ostrym mieczem” $(49,2)$. Różnica jednak polega na tym, że u Izajasza usta sługi JHWH są porównane do ostrego miecza, podczas gdy w Apokalipsie z ust Syna Człowieczego wychodzi „miecz”, który jest „ostry i obosieczny”. Mieczem tym jest Słowo, które nieustannie „wychodzi” (imiesłów czasu teraźniejszego) z ust Jezusa i posiada niezwykłą moc osądu rzeczywistości, co wyrażają przez dwa przymiotniki: „ostry” i „obosieczny”, które podkreślają ogromną moc słowa Bożego. To sformułowanie przypomina także Hbr 4,12, gdzie słowo Boże zostało określone jako „żywe i ostrzejsze niż miecz obosieczny”. W Apokalipsie tak rozumiane Słowo dokonuje sądu nad Kościołem $(2,12.16)$ oraz przeciwnikami Chrystusa i Boga $(19,15)$. Słowo to jednak służy nie tyle sądowi potępienia, lecz jest również wezwaniem do nawrócenia i przemiany życia.

Ostatni element wizji odnosi się do oblicza Syna Człowieczego, które „jaśniało jak słońce w swej mocy" $(1,16)$. Możliwy jest tu kontakt literacki ze Starym Testamentem, szczególnie z Sdz 5,31, gdzie Pieśń Debory kończy się życzeniem: „niech tak zginą wszyscy Twoi wrogowie, Panie, a ci, którzy Cię miłują, niech będą jak wschodzące słońce w całym swoim blasku!" W Apokalipsie akcent położony jest jednak nie na wschodzące słońce, lecz na słońce, które „świeci pełnią swojego blasku”, gdyż Jedyne Słońce - zmartwychwstały Pan już wzeszło i napełnia teraz swoim blaskiem oraz chwałą całą ziemię. W Apokalipsie słońce ma także znaczenie symboliczne jako szczególnie cenny dar Boga. Oblicze Chrystusa wyraża całą Jego osobę, która jest jak słońce, to znaczy jest bezcennym darem Boga dla Kościoła. Tak jak słońce przynosi radość, kreatywność, życie, tak Chrystus zmartwychwstały komunikuje te wszystkie dary wspólnocie Kościoła. Tak jak ludzie doświadczają zbawiennej roli słońca, tak w Chrystusie odnajdują „energię” potrzebną do wzrostu i życia duchowego ${ }^{54}$.

53 Zob. P. Ostański, Objawienie, s. 81; zob. także D. Kotecki, Zagadkowe wyrażenie, s. 257-271.

54 Zob. U. Vanni, L’Apocalisse, s. 133-136. Autor zwraca także uwagę na możliwość dostrzeżenia w tym elemencie intertekstualnej zależności z opisem przemienienia, szczególnie z Mt 17,2, gdzie mowa, że „Jego twarz zajaśniała jak słońce”, por. s. 115 oraz 135 przypis 46; podobnie P. Ostański, Objawienie, s. 82. 
Pierwsza część kończy się opisem reakcji Jana na chrystofanię Zmartwychwstałego: „gdy Go ujrzałem, padłem do Jego nóg jak martwy” $(1,17)$. Widzimy tu silnie wyakcentowany fakt, że reakcja wizjonera jest konsekwencją tego, co zobaczył. Została ona wyrażona w charakterystyczny sposób znany już w Starym Testamencie (por. Ez 1,28; Dn 8,17; 10,9), jako reakcja człowieka na ukazywanie się istoty transcendentnej ${ }^{55}$. Jan upada jakby martwy do stóp Jezusa. Chodzi tu o postawę adoracji (por. także Ap 19,10 oraz 22,8-9), ale też w naszym kontekście reakcja ta może wyrażać strach $(\mathrm{Mt} 28,4)$. Odniesienie do Ewangelii według Mateusza wydaje się szczególnie interesujące ze względu na bardzo podobny kontekst zmartwychwstania Jezusa. Wobec zstąpienia anioła Pańskiego $(28,2)$ strażnicy „odczuli strach i stali się jakby martwi” Podobne sformułowanie odnajdujemy w Apokalipsie w odniesieniu do wizjonera z Patmos: „jak martwy”. Wskazuje ono na intensywność przeżycia i doświadczenia opisywanej rzeczywistości, choć też jednocześnie podkreśla fakt, że mamy do czynienia z transcendencją i objawieniem się samego Boga (por. Dz 22,7).

Chrystus odpowiada najpierw na reakcję Jana gestem: „położył swoją prawicę". Wyraża on pomoc, wsparcie, umocnienie, pocieszenie. W przypadku powołań prorockich jest to charakterystyczny gest oznaczający zapewnienie pomocy i opieki, mający zachęcić powołanego do podjęcia zleconej przez Boga misji (Dn 10,10.18). W Nowym Testamencie podobny gest pojawia się w kontekście wskrzeszenia (Mk 5,23.41). Dla Jana spotkanie ze Zmartwychwstałym jest komunikacją nowego życia, jest wyprowadzeniem go ze stanu „śmierci”, a jednocześnie początkiem powierzenia mu nowego zadania. Autor precyzuje, że chodzi o „prawą rękę” Syna Człowieczego, którą dotyka Jana. Została ona wspomniana już wcześniej w 1,16, a w 1,20 ponownie przywołana w wyjaśnieniu symbolu siedmiu gwiazd. W ten sposób Autor podkreśla pozytywną siłę i autorytet, z którym Syn Człowieczy przekazuje Janowi konkretne zadanie wobec wspólnoty kościelnej.

Czynności „ożywienia” towarzyszą słowa, potwierdzające wymowę gestu Jezusa w 1,17: „nie lękaj się". To kolejny charakterystyczny element epifanii samego Boga ( $\operatorname{Rdz} 15,1 ; 26,24 ; 46,3 ; \mathrm{Sdz} 6,23$; Iz 43,1; 44,2) i aniołów (Dn 10,12.19; Tb 12,17; Mt 28,5; Łk 1,13.30; 2,10), który przezwycięża ludzką słabość i przygotowuje człowieka do podjęcia misji powierzonej mu przez Boga lub w Jego imieniu.

Nawet jeśli od początku wizji intuicyjnie można odczytywać, że chodzi o Jezusa zmartwychwstałego, to dopiero autoprezentacja pozwala na taką jednoznaczną identyfikację, gdyż zawiera ona pięć tytułów, odnoszących się do Jezusa, ułożonych w sposób koncentryczny $(1,17 b-18)$ :

55 Zob. C. Doglio, Il Primogenito, s. 99, przypis 32 i 33. 
A Ja jestem ( $\in$ i $\mu \iota)$ Pierwszy i Ostatni

B i Żyjący $(\zeta \hat{\omega} \nu)$

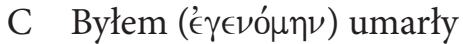

B' a oto jestem Żyjący ( $\zeta \hat{\omega} \nu)$ na wieki wieków

A' i mam (' $€ \chi \omega)$ klucze Śmierci i Otchłani

W samym centrum znajduje się jedyna forma czasownikowa w czasie przeszłym ('€ $\gamma \in \nu o ́ \mu \eta \nu)$, wyrażająca fakt śmierci Jezusa. Ramy stanowi podwójne użycie imiesłowu czasu teraźniejszego ( $\zeta \omega \nu)$, który oznacza aktualny stan, pozostający w kontraście do wydarzenia śmierci. Na początku zaś i na końcu mamy dwa czasowniki w trybie oznajmującym czasu teraźniejszego ( $\left.\epsilon i \mu \mathrm{l},{ }^{\prime} \in \chi \omega\right)$, które charakteryzują istotę i działanie Zmartwychwstałego.

Autoprezentacja rozpoczyna się od uroczystego „ja Jestem”, które niesie w sobie bardzo ważne znaczenie teologiczne. Najpierw w najbliższym kontekście nawiązuje do autoprezentacji Boga w 1,8: „Ja jestem Alfa i Omega, mówi Pan Bóg, który jest, który był i który przychodzi, wszechwładny". W ten sposób zostaje wyrażona myśl, że Syn Człowieczy-Zmartwychwstały Chrystus

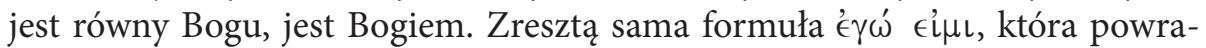
ca dwadzieścia cztery razy w Ewangelii Janowej oraz pięć razy w Apokalipsie, została zaczerpnięta ze Starego Testamentu i odnosi się zawsze do Boga albo Chrystusa. W Apokalipsie formuła ta nigdy nie występuje w formie absolutnej, jak to bywa czasami w Ewangelii Janowej (6,20; 8,24.28.58, także w Mt 14,27; Mk 6,50), ale zawsze towarzyszą jej określenia, które w Starym Testamencie odnoszą się do Boga $(1,8.17 ; 2,23 ; 21,6 ; 22,16)$. Prawidłowość ta odsłania nam intencję teologiczną Autora, który konsekwentnie opisuje postać Zmartwychwstałego przy pomocy wyrażeń typowych dla Boga. Mamy wymowny przykład chrystologii teocentrycznej typowej dla Apokalipsy56.

Jezus jest „Pierwszy”, to znaczy jest ostateczną zasadą i racją stworzonego i odkupionego świata ${ }^{57}$, Pierworodnym spośród umarłych $(1,5)$. Jest także „Ostatni”, bo wypełnia definitywnie (eschatologicznie) plan Boży, jest Panem historii, eschatologicznym Sędzią i jednocześnie daje początek nowemu stworzeniu $^{58}$. Jako „Pierwszy i Ostatni” jest równy Bogu (chrystologia teocentryczna), który jest „Alfą i Omegą” (1,8), co staje się oczywiste w świetle 22,13, gdzie Jezus został wprost opisany przy pomocy paralelnych, synonimicznych określeń jako „Alfa i Omega, Pierwszy i Ostatni, Początek i Koniec”.

56 Zob. D. Kotecki, Reinterpretación, s. 509-524.

57 Zob. A.R. Sikora,'A $\rho \chi \dot{\eta}$, s. 319-328.

58 Zob. G. O’Collins, Christology, s. 147. 
Trzeci tytuł Jezusa „i Żyjący” odsyła do Starego Testamentu, gdzie Bóg jest często określany jako „Żyjący” w Pwt 5,26; 1 Sm 17,26.36; Jr 10,10; 23,26; Dn $6,27)^{59}$. Bóg jest jedynym źródłem życia. On ma życie w sobie samym w odróżnieniu od „idoli”, którzy są martwi. W Apokalipsie imiesłów „Żyjący” jest użyty jeszcze cztery razy w odniesieniu do Boga $(4,9.10 ; 10,6 ; 15,7)$.

Do tej chwili autoprezentacji objawiającego się Chrystusa można mieć przekonanie, że mamy do czynienia z samym Bogiem. Wiele elementów, które zostały wskazane $\mathrm{w}$ analizowanym tekście, pozwalają odczytywać wizję w kontekście starotestamentalnych odniesień i aluzji do Boga. Jednak dopiero teraz pojawia się element, który umożliwia jednoznaczną identyfikację Syna Człowieczego z Chrystusem. Mówi o sobie: „byłem umarły”. Nie jest możliwe odniesienie tego określenia do Boga. Autor Apokalipsy wybiera dość nieoczekiwany sposób mówienia o śmierci Jezusa. Stosuje konstrukcję peryfrastyczną, złożoną z dwóch elementów. Najpierw przy pomocy aorystu czasownika „sta-

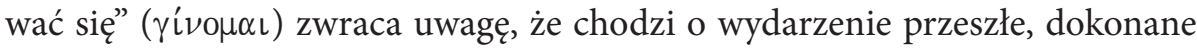
i momentalne (punktowe), które jest w pewnym kontraście do stanu aktualnego i trwającego, wyrażonego przy pomocy imiesłowów czasu teraźniejszego. W ten sposób zostaje podkreślony historyczny fakt śmierci Jezusa, a samo sformułowanie jest elementem pamięci o tym wydarzeniu. Użycie przymiotnika „umarły” ( $v \in \kappa \rho o ́ \varsigma)$ wskazuje natomiast na realizm śmierci, na fakt stania się trupem, podkreślając walor fizyczny śmierci, jej okrucieństwo i przemoc, co jest także wyraźną aluzją do śmierci krzyżowej Chrystusa. Dzięki też zastosowaniu konstrukcji peryfrastycznej, która nie jest spotykana w tradycji na określenie śmierci Jezusa (należałoby oczekiwać czasownika ảmo $\theta \nu \eta ̣ ́ \sigma \kappa \omega)$, Autor akcentuje podwójny kontrast między zaistnieniem historycznym w czasie (śmierć rozumiana jako konsekwencja Wcielenia i pełne uczestnictwo w śmiertelnej naturze człowieka) a wiecznym trwaniem Boga oraz między życiem a śmiercią. Ten ostatni kontrast staje się jeszcze bardziej paradoksalny, ponieważ oba określenia „Żyjący” i „martwy” odnoszą się do tej samej osoby.

Kolejny element autoprezentacji nawiązuje do zmartwychwstania Jezusa, który „był umarły”, ale jak sam mówi: „oto jestem Żyjący na wieki wieków”. Zastosowana formuła nie tyle podkreśla sam fakt zmartwychwstania (brakuje znowu typowych czasowników, opisujących w tradycji zmartwychwstanie Chrystusa, np. '€ $\left.\gamma \in i \rho \omega^{60}\right)$, co raczej podkreśla stan, sposób bycia, aktualny i permanentny, na co wskazuje dość nieoczekiwane wyraźne połączenie imiesłowu z czasownikiem „być” w czasie teraźniejszym ( $\zeta \hat{\omega} \nu \in \grave{l} \mu \iota)$. Służy raczej opisaniu 
stanu trwania i może być uznane za „praesens wieczności”61. W zestawieniu z poprzednim czasownikiem w aoryście, który odnosił się do śmierci krzyżowej Jezusa oznacza tyle, że Jezus zmartwychwstając, zwyciężył śmierć, wyzwolił się z jej więzów, zrzucił z siebie jej brzemię. Jest to zatem proklamacja Jego zwycięstwa nad śmiercią ${ }^{62}$. Jezus jest Żyjący, ponieważ jest Bogiem (ó $\left.\zeta \hat{\omega} \nu\right)$, ale także dlatego, że zwyciężył śmierć i przeszedł ze śmierci do życia. Zmartwychwstanie jest więc rozumiane jako akt mocy Bożej, ale i samego Jezusa.

Stosując wyrażenie odnoszące się do zmartwychwstania Jezusa, Autor podkreśla bardzo mocno, że nie chodzi tylko o zwykły powrót do poprzedniego stanu życia, takiego jakie miał Jezus przed śmiercią. Teraz jest On „Żyjący na wieki wieków”. Z jednej strony należy widzieć w tym dopowiedzeniu liturgiczny charakter wyznania wiary w śmierć i zmartwychwstanie Jezusa przez wspólnotę pierwotnego Kościoła, z drugiej wpisuje się w tradycyjne rozumienie zmartwychwstania Jezusa jako uczestnictwa w wiecznym życiu samego Boga (por. Rz 6,9-10). To dzięki przejściu ze śmierci do życia staje się „Żyjącym” na wieki. Przypomnijmy, że w Apokalipsie sam Bóg jest nazywany „Żyjącym na wieki wieków” (4,9.10; 10,6; 15,7). Dzięki zmartwychwstaniu Jezus ma udział w odwiecznym życiu Boga i stał się także źródłem tego życia dla innych ${ }^{63}$. Warto zauważyć, że w całej wizji Apokalipsy dopiero sformułowania, odsyłające nas do pamięci o misterium paschalnym, pozwalają na jednoznaczną identyfikację „podobnego do Syna Człowieczego" z Jezusem Chrystusem. Nie jest to ani sam Bóg, ani anioł, lecz Ukrzyżowany i Zmartwychwstały. Wskazuje to na fundamentalne znaczenie tego wydarzenia zbawczego i przywoływania go w pamięci wspólnoty jako kryterium własnej tożsamości oraz identyfikacji samego Chrystusa obecnego w Kościele. Chociaż misterium paschalne Jezusa jako wydarzenie (fakt historyczny) należy do historii, to jednak jest nieustannie przywoływane w pamięci i uobecniane w celebrowanej liturgii.

Ostatni element autoprezentacji Jezusa wskazuje na to, że On nie tylko jest Żyjący, ale jest także Panem życia. Symbolicznie zostało to wyrażone w obrazie posiadania „kluczy Śmierci i Otchłani”. Posiadać klucze oznacza symbolicznie mieć władzę i panowanie (por. 3,7; 9,1; 20,1). Bazą tego symbolicznego sformułowania jest niewątpliwie tradycja biblijna $(\mathrm{Ez} 37,12)$ oraz literatura judaistyczna (Targum Neofity i Pseudo-Jonatana). Cała tradycja bardzo jednoznacznie podkreśla, że tylko Bóg jest w posiadaniu tych kluczy. We wspomnianym Targumie Neofity czytamy, że nie zostały one powierzone ani aniołom, ani se-

61 P. Prigent, L’Apocalypse, s. 108; D.E. Aune, Revelation, s. 102: „serves to describe a situation".

62 Zob. J. Comblin, Le Christ, s. 204.

63 Zob. M. Wojciechowski, Zmartwychwstanie, s. 265. 
rafinom. Tekst Apokalipsy kolejny raz, to co było wyłącznym atrybutem Boga, przypisuje Chrystusowi, który „ma klucze śmierci”, to znaczy całkowicie panuje nad śmiercią, gdyż zwyciężył ją przez swoje zmartwychwstanie ${ }^{64}$.

Po autoprezentacji Jezus poleca Janowi spisanie wszystkiego w słowach: „,napisz więc, co widziałeś i co jest, i co potem się stanie" $(1,19)$. Polecenie to przypomina wcześniejsze z 1,11, kiedy to Jan otrzymał zadanie spisania wszystkiego i wysłania Kościołom Azji Mniejszej. Jan jest zatem przekazicielem i świadkiem tego, co otrzymał od Chrystusa (por. 1,1). W pewien subtelny sposób Autor akcentuje autorytet przekazywanego słowa, a skoro jest to z polecenia Chrystusa zmartwychwstałego, to nie może nie zostać przyjęte przez wspólnotę Kościo$\nmid a^{65}$. Autentyczność przesłania została także wyrażona przez nagromadzenie w całej wizji czasowników, odnoszących się do widzenia (1,11.12bis.17.19.20), mówienia $(1,11.12 .16 .17)$ i słuchania $(1,10)$. W ten sposób zostaje podkreślony bezpośredni kontakt wizjonera $\mathrm{z}$ Chrystusem i autentyczność przekazanego świadectwa. Jest on naocznym świadkiem Zmartwychwstałego i przekazuje to, co otrzymał bezpośrednio od Niego samego, a całą wizję można określić jako epifanię paschalną na wzór tych ewangelicznych. Ta bezpośredniość spotkania Jana z Chrystusem jest gwarancją prawdziwości i autentyczności jego świadectwa przekazanego na piśmie.

Ostatni werset $(1,20)$ jest glosą wyjaśniającą tajemnicę siedmiu gwiazd i siedmiu świeczników ${ }^{66}$ : „Poznaj tajemnicę siedmiu gwiazd, które widziałeś w mojej prawicy, i siedmiu złotych świeczników: siedem gwiazd to aniołowie siedmiu Kościołów, a siedem świeczników to siedem Kościołów”. Sam Jezus

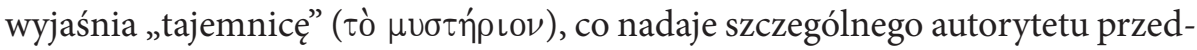
stawionemu wyjaśnieniu. Siedem gwiazd, które są w ręku Jezusa to aniołowie siedmiu Kościołów, a więc tych, którzy są odpowiedzialni za poszczególne Kościoły lokalne. Pozostają oni w ręku Jezusa, to znaczy całkowicie podlegają Jego władzy i panowaniu. Drugi element dopełnia symbolizm. Kościół jest widziany w swojej pełni. Siedem świeczników ze złota to siedem Kościołów. Chodzi zatem o cały Kościół (symbolizm liczby siedem) pozostający w bezpośrednim kontakcie z transcendencją (kolor złoty świeczników) i będący światłem dla świata. To właśnie do niego jest adresowane przesłanie Jana $(1,11)$, zawierające autentyczne objawienie Boga w Jezusie, które jest słowem nadziei dla Kościoła każdego czasu i miejsca.

Zob. F. Sieg, Implikacje, s. 232-234. 


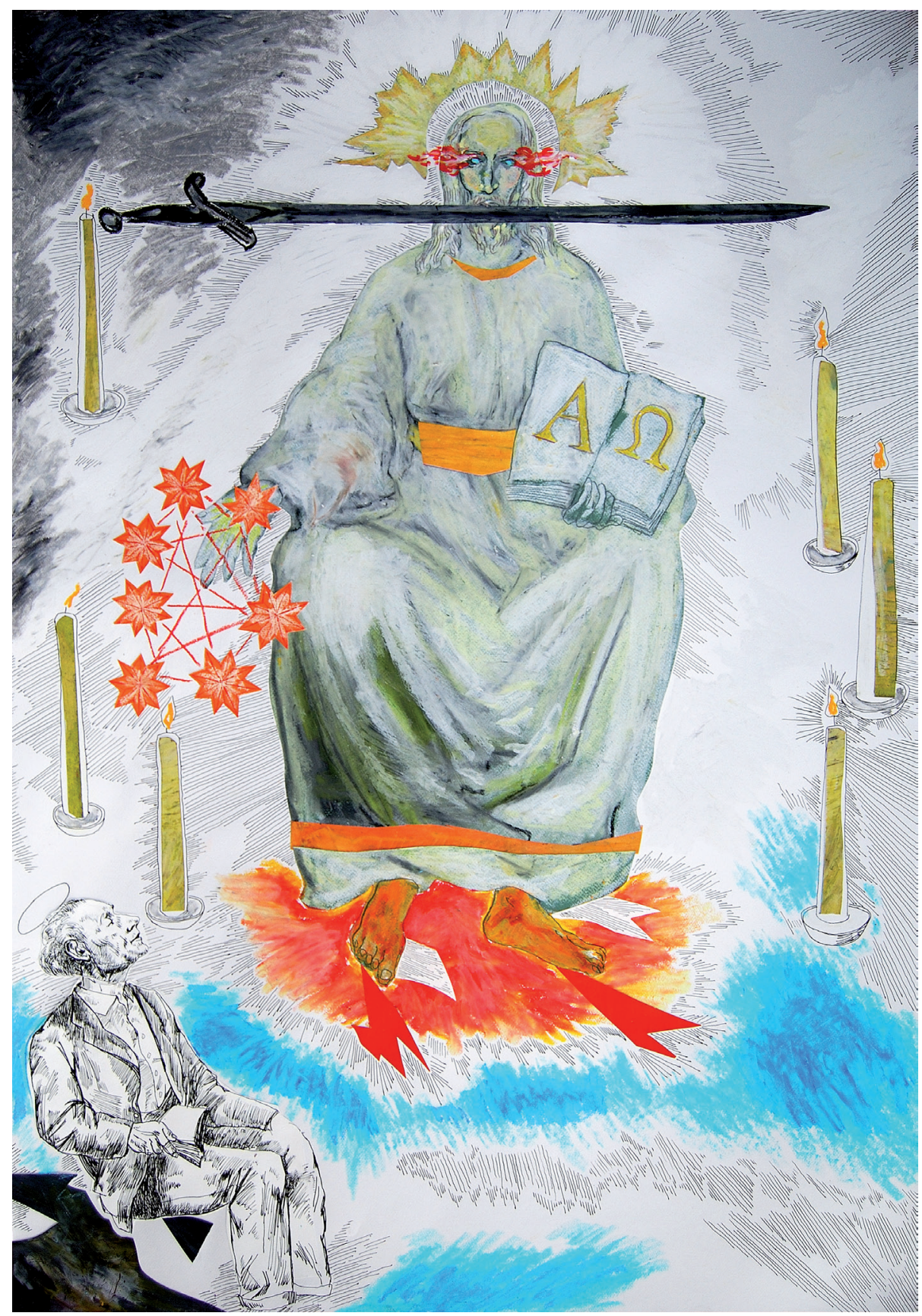

Ilustracja z Apokalipsy świętego Jana Apostoła. Przekład z języka greckiego i komentarz ks. Jan Kanty Pytel. Ilustracje Grzegorz Bednarski, Poznań 2008, s. 71 


\section{3. „Pan świeczników i gwiazd” (Ap 1,12-20) według G. Bednarskiego}

Pierwsza ilustracja przygotowana przez artystę inspiruje się wizją wstępną Apokalipsy, „która zdaje się szkicować ogromną ikonę, w której centrum stoi postać Chrystusa" ${ }^{\prime}$. Jest to rysunek tuszem, olej, pastel, kolaż, o wymiarach $100 \times 70 \mathrm{~cm}$. Biorąc pod uwagę wszystkie ważniejsze elementy wizji, które zostały omówione $\mathrm{w}$ poprzednim punkcie, kontemplując obraz Bednarskiego, spróbujmy odpowiedzieć na pytanie: na ile zaproponowane dzieło jest ilustracją tekstu biblijnego, a na ile jego interpretacją?

Zacznijmy od wizjonera Jana ${ }^{68}$. Został on przedstawiony w lewym dolnym narożniku ilustracji. Ma na sobie współczesny ubiór, co wyraża prawdę, że całe przesłanie Apokalipsy nie jest tylko historyczne, ale ponadczasowe (transhistoryczne) i odnosi się także do współczesnego odbiorcy. Jan unosi głowę do góry w kierunku „podobnego do Syna Człowieczego”, zatem ku niebu, ku transcendencji. Pozostaje w pozycji siedzącej, kontemplując to wszystko, co widzi i słyszy, ale jednocześnie trzyma na kolanach otwartą księgę, niezapisany notes, co wyraża jego gotowość do spisywania tego wszystkiego, co zostało mu objawione, zgodnie zresztą z nakazem Chrystusa $(1,19)$. Artysta przedstawia zatem Jana $z$ drugiej części wizji, kiedy dotknięty przez prawicę Jezusa powstał z głębokiego ukłonu adoracji $(1,17)$ i jest gotowy na poznawanie objawiającej się mu tajemnicy.

W centrum ilustracji znajduje się „podobny do Syna Człowieczego”, to znaczy zmartwychwstały Chrystus. Zgodnie z opisem biblijnym ma On na sobie długą "szatę sięgającą aż do stóp” $(1,13)$ i jest „przepasany na piersiach złotą szarfą" (1,13), co wskazuje na Jego godność arcykapłańską i królewską. Jego głowa i włosy są „niczym śnieżnobiała wełna, Jego oczy jak płomień ognia” $(1,14)$. Z jednej strony jest jak Starowieczny $(\mathrm{Dn} 7,9)$, ale nagromadzenie koloru białego (włosy oraz wokół głowy) wskazują na zmartwychwstałego Jezusa, który oczami „jak płomień ognia” pełnymi miłości i troski rozpoznaje, ale też osądza sytuację wspólnoty. Płomień ognia ma także moc puryfikacji i wypalenia tego wszystkiego, co nie jest zgodne z Jego wolą.

67 G. Ravasi, Apokalipsa, s. 24.

68 Zdaniem R. Rogozińskiej, Apokalipsa, s. 114 w wizerunku natchnionego proroka rozpoznajemy Wojciecha Kilara, podobnie jak w ostatniej ilustracji. Zdaniem autorki artykułu, „przedstawienie to można potraktować jako wyraz atencji dla muzycznych dokonań znanego kompozytora, w których zawsze ważną rolę odgrywały inspiracje religijne i głęboka wiara własna”. 
Dalej zgodnie z wizją Apokalipsy, Jego „nogi jakby z drogocennego kruszcu w piecu rozżarzonego" $(1,15)$, co zostało wyrażone przez intensywność koloru czerwonego (ognistego), który odmalowano nogi Jezusa. Warto zauważyć, że żar ognia niejako promieniuje z nóg Jezusa, co może być aluzją, podobnie zresztą jak w tekście Apokalipsy, do wizji Przedwiecznego (Dn 7,9-10), w której „ognista rzeka wypływała i wydobywała się sprzed Niego” (Dn 7,10).

W prawej ręce „ma siedem gwiazd” $(1,16)$, które są ze sobą połączone liniami, być może symbolizującymi jedność gwiazd, które wszystkie w takim samym stopniu pozostają w "prawej ręce” Jezusa, to znaczy w Jego władzy, opiece i trosce. Jego prawica wyciągnięta jest w kierunku wizjonera, zgodnie ze słowami: „położył na mnie swoją prawicę" $(1,17)$.

$\mathrm{Z}$ „ust Jego wychodzi miecz ostry obosieczny” $(1,16)$, który bez wątpienia zwraca uwagę odbiorcy. Jest on bardzo wyraźnie zaznaczony i mogłoby się nawet wydawać, że jest nieproporcjonalnie duży w porównaniu z innymi elementami obrazu, jak np. świeczniki. W ten sposób artysta wyraża moc słowa Bożego, które wychodzi z ust Jezusa. Miecz jest potężny i wielki, bo wielka jest potęga Bożego słowa. Być może ta wielkość miecza Bożego jest też inspirowana wcześniejszym sformułowaniem, że "głos Jego jak szum spiętrzonej wody” $(1,15)$, co przecież wydaje się bardzo trudne czy nawet wręcz niemożliwe do zobrazowania. Potężny miecz słowa Bożego, który wychodzi z ust Jezusa (por. 2,16 i 19,15) oznacza, że ,jego słowo nie jest zwykłym tchnieniem powietrza, lecz to skuteczny wyrok, który osądza i natychmiast uderza w grzech świata, unicestwia go (por. Iz 11,4; 49,2)" ${ }^{69}$.

Tekst biblijny mówi jeszcze o Jezusie, że „Jego oblicze jaśniało jak słońce w swojej mocy" $(1,16)$. Artysta odmalowuje twarz Jezusa żółtym kolorem, a nad Jego głową promienieje niezwykła „aureola paschalnego światła”70, „jak słońca w swojej mocy".

W lewej ręce Jezus trzyma księgę z greckimi pierwszą i ostatnią literą alfabetu greckiego. W ten sposób artysta wyraża prawdę wizji, że Jezus jest „Pierwszy i Ostatni” $(1,17)$ i jest jednocześnie nawiązaniem do 1,8, gdzie sam Bóg nazwany jest „Alfa i Omega” oraz jeszcze bardziej do 22,13, gdzie Jezus został określony jako „Alfa i Omega, Pierwszy i Ostatni, Początek i Koniec”. Te same zatem tytuły odnoszą się paralelnie do Boga i Jezusa, co wyraża prawdę o Jezusie jako Bogu (teocentryzm chrystologiczny).

Na obrazie Bednarskiego „podobny do Syna Człowieczego” przedstawiony został w pozycji siedzącej. Tekst biblijny nie precyzuje w jakiej pozycji wizjoner zobaczył Zmartwychwstałego Pana. Pewną pomocą może być informacja z li-

70 Ibidem. 
stu do Kościoła w Efezie, gdzie w autoprezentacji Jezus mówi o sobie, że „władczo trzyma w swojej prawicy siedem gwiazd i chodzi pośrodku siedmiu złotych świeczników” $(2,1)$. Artysta decyduje się jednak przedstawić „podobnego do Syna Człowieczego" jako siedzącego. Zaproponowana interpretacja wydaje się całkowicie zgodna z przesłaniem Apokalipsy. Wielokrotnie zwracaliśmy uwagę na charakterystyczny dla Księgi teocentryzm chrystologiczny, polegający na przedstawianiu Jezusa przy pomocy określeń i obrazów, które w Pierwszym Testamencie odnoszą się do jedynego Boga Izraela. Jest to sposób wyrażenia prawdy, że Jezus jest Bogiem. Według Apokalipsy Bóg jest „Zasiadającym na tronie” (4,2), „Alfą o Omegą” $(1,8)$, „Wszechwładnym” $(1,8)$, a „Baranek stojący, jakby zabity" $(5,6)$, to znaczy Chrystus ukrzyżowany i zmartwychwstały, pojawia się „pośrodku tronu” $(5,6)$. Jak zauważa ks. Kotecki, „Baranek pojawia się w centrum wszystkiego; tronu, czterech Istot Żyjących i Starszych. Baranek zajmuje miejsce "Zasiadającego na tronie”. Jest przedstawiony zatem w boskiej godności, na równi z Bogiem Stworzycielem, Panem historii. Nie oznacza to, że zastępuje «Zasiadającego na tronie», ale że niejako się z Nim stapia ze względu na boską naturę"71. Bednarski wyraża tę prawdę przedstawiając Jezusa „Zasiadającego na tronie", pełnego majestatu, o wyraźnych rysach królewskich i arcykapłańskich eschatologicznego Sędziego (charakterystyczna postawa siedząca sędziego wydającego wyrok), który mocą słowa „ostrego jak miecz obosieczny” osądza Kościół, co staje się oczywiste w dalszej lekturze Księgi, zwłaszcza listów do siedmiu Kościołów $(2,1-3,22)$, gdzie osąd wspólnoty stanowi istotny element przesłania Apokalipsy. Zdaniem R. Rogozińskiej, „w scenie Pan świeczników i gwiazd (Ap 1,12-20) «Pierwszy i Ostatni» z oczami «jak płomień ognia» (Andrzej z Cezarei pisał o nich: «te oczy oświecają świętych, a spalają grzeszników») i stopami «jakby z drogocennego kruszcu w piecu rozżarzonego» jawi się niczym Przedwieczny z romańskich portali, porażający majestatem i pełnią nieziemskiej mocy"72. Pani historyk sztuki z Poznania zauważa także bardzo słusznie, że taki sposób przedstawienia Chrystusa jest pewną odpowiedzią artysty na pojawiające się czasem nawet $w$ teologicznych dociekaniach próby łagodzenia obrazów Boga i Chrystusa jako sprawiedliwego Sędziego. Jak pisze „dzięki inwencji artysty, a przede wszystkim ekspresyjnemu charakterowi malarstwa, dzieło Bednarskiego nie stało się opowieścią o Bogu nadmiernie «rozmiękczonym» $\mathrm{i}$ «uładzonym» przez koncepcję «nowej religijności» (tonującej wymowę trudnych słów Biblii, by zniwelować w wiernych lęk przed karą oraz dać im psychiczny komfort płynący z nadziei, że po śmierci mogą liczyć na bezgraniczne miłosierdzie Boże) [...]. «Straszna to rzecz wpaść w ręce Boga żywe-

D. Kotecki, Jezus, s. 303.

72 R. Rogozińska, Apokalipsa, s. 110. 
go» - pisał św. Paweł w Liście do Hebrajczyków (10,30-31). Podobną intuicję odnaleźć można w innych wizjach Bednarskiego, wzbudzających raczej «strach pełen wewnętrznego drżenia» (misterium tremendum) aniżeli oczarowanie czy zachwyt (misterium fascinans)"73. Można by zatem zapytać: jakie emocje wywołuje w nas ilustracja Bednarskiego? Strach czy oczarowanie? Patrząc na Zmartwychwstałego stajemy wobec misterium tremendum czy raczej misterium fascinosum? Odpowiedź pozostawiam odbiorcy.

Kolejny ważny element wizji to „siedem świeczników”. Czytamy, że wizjoner zobaczył najpierw „siedem świeczników” $(1,12)$, a „w pośrodku zaś siedmiu świeczników ujrzałem kogoś podobnego do Syna Człowieczego" $(1,13)$. Zgodnie z interpretacją daną na końcu wizji „siedem świeczników to siedem Kościołów” $(1,20)$. Tekst biblijny zwraca uwagę, że Jezus jest obecny „pośród świeczników”, co jak powiedzieliśmy wcześniej symbolizuje bliskość Jezusa, Jego miłość i zainteresowanie względem każdej wspólnoty kościelnej, a tym samym całego Kościoła. Jednocześnie obecność świeczników jako nieodzownego elementu kultu przenosi nas w przestrzeń liturgiczną, która staje się uprzywilejowanym miejscem przeżywania obecność Zmartwychwstałego Chrystusa i słuchania Jego słowa. Patrząc na ilustrację Bednarskiego widzimy wyraźnie świeczniki, które przedstawione zostały jako pojedyncze świece, idąc za sformułowaniem kard. Ravasiego, które są „pewnego rodzaju rozczłonkowaniem tradycyjnego żydowskiego kandelabru siedmioramiennego (Wj 25,31-40: Za 4,1-14): każde światło teraz jest niezależne i odnosi się do siedmiu Kościołów" ". Siedem świec pochodzących z siedmioramiennego świecznika (menory), ale na ilustracji Bednarskiego jest ich sześć wyraźnie usytuowanych w kręgu, a pośrodku nich Chrystus. Pytanie jakie nasuwa się uważnemu obserwatorowi dzieła: gdzie jest siódmy świecznik? Można łatwo wyobrazić sobie, że skoro świece ustawione są $\mathrm{w}$ kręgu, a Jezus znajduje się pośrodku nich, to z perspektywy patrzącego na obraz siódmej świecy nie widać, ponieważ jest z tyłu za Jezusem. Inna możliwość interpretacyjna jest następująca: siódmym świecznikiem jest wspólnota, która dzisiaj patrzy na obraz i kontempluje Chrystusa zmartwychwstałego, obecnego o żyjącego w Kościele.

Patrząc jednak na ilustrację można odnieść także wrażenie, że siódmą świecą jest sam zmartwychwstały Chrystus (promienie - „płomienie” wychodzące w głowy Jezusa), a wyraźnie zaznaczone litery „Alfa” i „Omega” przywołują szczególną świecę, jak jest paschał, będący liturgicznym symbolem Chrystusa zmartwychwstałego. Zapala się go uroczyście w Wigilię Paschalną i stawia w centrum, aby proklamować radosne orędzie o zwycięstwie

\footnotetext{
73 Ibidem.

74 G. Ravasi, Apokalipsa, s. 25.
} 
Chrystusa nad śmiercią. I chociaż taka interpretacja nie jest do końca zgodna $\mathrm{z}$ tekstem biblijnym, bo siedem świeczników oznacza siedem Kościołów, to wpisuje się doskonale w przesłanie Apokalipsy, gdzie Baranek - Chrystus zmartwychwstały jest zawsze w centrum Kościoła, zwłaszcza gdy wspólnota gromadzi się na liturgii eucharystycznej, będącej pamiątką misterium paschalnego. A przecież warto przypomnieć, że wizja ma miejsce w „Dzień Pański” $(1,10)$ podczas liturgii.

Mając w pamięci tekst biblijny, patrzymy na ilustrację Bednarskiego i pytamy o werset 18, w którym mowa, „Ja jestem... i Żyjący, byłem wprawdzie umarły, a oto jestem Żyjący na wieki wieków i mam klucze Śmierci i Otchłani”. Nie ulega wątpliwości, że przedstawiony Jezus „podobny do Syna Człowieczego" jest „Żyjący na wieki wieków”, o czym świadczy także wcześniej wzmiankowana w tekście i odmalowana biel głowy i włosów Chrystusa oraz biel - jasność otaczające Jezusa. Chrystus, którego kontemplujemy tutaj, na pierwszy rzut oka nie nosi na sobie wyraźnych znaków męki (tak jak Baranek), które wskazywałyby jednoznacznie na historyczny fakt śmierci „byłem umarły”. Warto jednak zauważyć w tym kontekście dwa elementy. Pierwszy to czerwone plamy wychodzące ze stóp Jezusa, które w zestawieniu $\mathrm{z}$ inną ilustracją zatytułowaną „Baranek na górze Syjon, wysławiany pieśnią nową (Ap 154,1-5), gdzie jednoznacznie symbolizują krew Jezusa, także i tu kojarzą się z krwią wypływającą z przebitych gwoździami stóp Jezusa. Przy takiej interpretacji uwielbiony Pan nosi zatem na sobie wyraźne ślady męki, co doskonale wpisuje się w przesłanie teologiczne Apokalipsy. Drugie możliwe odniesienie do przejścia przez śmierć można zobaczyć w czarnym kolorze, którzy pojawia się w górnym lewym narożniku. Zmartwychwstały Pan przeszedł przez ciemność śmierci, zostaje ona całkowicie rozjaśnione przez blask zmartwychwstania, pozostaje jednak w pamięci i stanowi element ludzkiego życia. Czyżby czerń, która pojawia się w bliskości wizjonera symbolizowała także śmierć jako nieodzowny element ludzkiej historii? Jeśli tak to przesłanie jest jednoznaczne: człowiek kontemplując (celebrując) z wiarą tajemnicę paschalną w sakramentach, zwłaszcza chrzcie i Eucharystii, już „jest po stronie Jezusa”. Śmierć ma niejako za plecami, to znaczy choć nieuchronnie przyjdzie kiedyś, już dzisiaj może być pewny zwycięstwa w Chrystusie zmartwychwstałym.

Gdzie są jednak „klucze Śmierci i Otchłani”? Nie znajdujemy ich wyraźnie na ilustracji. Ale są prawda o nich wyrażona jest w całości kompozycji przedstawiających Zmartwychwstałego, co znowu doskonale wpisuje się w teologię Księgi Baranka. Powiedzieliśmy, że posiadanie kluczy symbolizuje absolutną 
władzę Jezusa nad śmiercią i otchłanią. Zgodnie z przesłaniem Apokalipsy zwycięstwo Jezusa nad śmiercią i otchłanią już dokonało się w Jego zmartwychwstaniu i jest definitywne. Zatem tylko On może otworzyć otchłanie, aby uwolnić zmarłych i zamknąć śmierć, aby ją odizolować ${ }^{75}$. Stąd sam fakt, że kontemplujemy Zmartwychwstałego jest równoznaczny z rozpoznaniem w Nim jedynego Pana życia i śmierci.

\section{Zakończenie}

Zaproponowana analiza ilustracji G. Bednarskiego prowadzi jednoznacznie do wniosku, że stworzone przez niego dzieło jest jednocześnie ilustracją i artystyczną interpretacją tekstu biblijnego. $\mathrm{Z}$ jednej strony bardzo uważnie czyta tekst Apokalipsy i z szacunkiem stara się wiernie go zilustrować. Wiele elementów jego dzieła odpowiada wprost detalom zapisanym w Ap 1,12-20. O jaką wierność jednak chodzi? Wierność, która jest tylko i wyłącznie dosłownością, wiernością, „co do litery”? Kontemplując dzieło Bednarskiego dochodzimy do przekonania, że chodzi o wierność profetycznemu charakterowi Księgi Objawienia. Nawet jeśli czasami artysta pozostaje mniej dosłowny i wprowadza mniej lub bardziej subtelne zmiany to jednak udaje mu się z niemałym powodzeniem pozostać wierny transhistorycznemu przesłaniu Apokalipsy. Podobnie jak wizjoner otrzymał polecenie, aby napisać, co widział „i co jest, i co potem musi się stać” $(1,19)$ i co zresztą wiernie uczynił w Księdze, tak samo G. Bednarski pragnie zilustrować to co sam zobaczył, czytając tekst Apokalipsy, i co jest zawsze aktualne, i co stanie się niebawem (por. 1,3), co w języku apokaliptycznym nie oznacza bliskości chronologicznej, ale pewność i niezawodność wydarzenia, które jest prorocko zapowiadane. Świadomie używam sformułowania, że artysta „pragnie zilustrować”, bo przecież sztuka ilustrowania, jak wskazuje na to etymologia łacińskiego illustro to przede wszystkim umiejętność „czynienia jasnym” i „tłumaczenia”76. W przypadku Bednarskiego okazuje się ona także sztuką interpretacji i aktualizacji orędzia biblijnego. W ten sposób i przy tak rozumianej wierności tekstowi biblijnemu artysta staje się egzegetą, który pędzlem maluje i wydobywa przesłanie, staje się "głosem”, który „można i trzeba zobaczyć, także po to, aby lepiej go zrozumieć. W ten sposób obraz komunikuje to, co niewyobrażalne, a jednak ważne, konieczne i niezbędne. Trudno nie zgodzić się z R. Rogozińską, która pisze, że „ryzyko, jakie podjął Grzegorz Bednarski, opłaciło

\footnotetext{
75 Zob. M. Wojciechowski, Apokalipsa, s. 120.

76 Zob. R. Rogozińska, Apokalipsa, s. 98.
} 
się co najmniej w dwójnasób. W efekcie zrodziła się bowiem nie tylko bibliofilska książka, w której słowo i obraz wzbogacają się i dopełniają wzajemnie, łącząca tradycje z nowoczesnością, nadzieję i miłość lękiem przed gniewem Stwórcy i jego nieubłaganą sprawiedliwością. W dalszej kolejności tym razem już z inicjatywy samego artysty, powstały bowiem następne obrazy, odnoszące się do wszystkich dwudziestu dwóch rozdziałów"77. Pozostaje tylko żywić nadzieję, że prace Bednarskiego staną się dostępne coraz szerszemu kręgowi odbiorców i będą nie tylko wymownym świadectwem ciągle żywego oddziaływania Biblii na sztukę także współczesną, ale przede wszystkim pomogą zwłaszcza ludziom wierzącym, dla których Apokalipsa jest Słowem Boga, odkryć, czasem głęboko ukryte orędzie nadziei i pocieszenia, którego tak bardzo potrzebujemy w każdym czasie.

\section{Bibliografia}

Apokalipsa świętego Jana Apostoła, Przekład z języka greckiego i komentarz ks. Jan Kanty Pytel. Ilustracje Grzegorz Bednarski, Poznań 2008.

Aune D.E., Revelation 1-5, Nashville 1997.

Beale G.K., The Book of Revelation, Grand Rapids 1999.

Benedykt XVI, Verbum Domini, Kraków 2010.

Biguzzi G., Apocalisse, Torino 2005.

Charlesworth J.H., The Jewish Roots of Christology: The Discovery of the Hypostatic Voice, SJT (39)1986, s. 19-41.

Comblin J., Le Christ dans l’Apocalypse, Paris-Tournai 1965.

Doglio C., Il Primogenito dei morti. La risurrezione di Cristo e dei cristiani nell'Apocalisse di Giovanni, Bologna 2005.

Gądecki S., Wstęp do pism Janowych, Gniezno ${ }^{2} 1996$.

Gryczyński M., Zrozumieć przesłanie Apokalipsy. Wywiad z ks. prof. Janem Kantym Pytlem, „Przewodnik Katolicki” 28(2008), https://www.przewodnik-katolicki.pl/ Archiwum/2008/Przewodnik-Katolicki-28-2008/Wiara-i-Kosciol/Zrozumiec-przeslanie-Apokalipsy, [dostęp: 02.10.2017].

Hanna K.F.A., La passione di Cristo nell'Apocalisse, Roma 2001.

Jankowski A., Syn Człowieczy w Janowej Apokalipsie (Ap 1,13; 14,14), PTom 1(1984), s. 39-48.

Jelonek T., Biblia w kulturze świata, Kraków 2007.

Jelonek T., Biblijna teologia kapłaństwa, Kraków 2006.

Knapiński R., Egzegeza biblijna w sztuce - słowo obrazem się staje, w: Biblia kodem kulturowym Europy, red. S. Szymik, Lublin 2013, s. 45-75.

77 Ibidem, s. 113. 
Kotecki D., Duch Święty w zgromadzeniu liturgicznym w świetle Apokalipsy św. Jana, Warszawa 2006.

Kotecki D., Jezus a Bóg Izraela w Apokalipsie św. Jana, Toruń 2013.

Kotecki D., Kryteria interpretacji Apokalipsy, BPT 5(2012), s. 15-34.

Kotecki D., Reinterpretación del Antiguo Testamento en el Nuevo: cristología teocéntrica en el Apocalipsis de san Juan, ScT 40(2008)2, s. 509-524.

Kotecki D., Zagadkowe wyrażenie „anioł Kościoła” w Apokalipsie według św. Jana, ZNSBP 3(2006), s. 257-271.

Lupieri E., L’Apocalisse di Giovanni, [Roma] ${ }^{4} 2005$.

Malina A., Mistagogiczny i pedagogiczny charakter Przemienienia Pańskiego w narracji Marka (9,2-13), w: A. Żądło (red.), Mistagogia a duchowość, Katowice 2007, s. $170-181$.

Nota biograficzna G. Bednarskiego, http://www.galeria-attis.pl/artysta/grzegorz-bednarski/, [dostęp: 02.10.2017].

O'Collins G., Christology. A Biblical, Historical and Systematic Study of Jesus, Oxford ${ }^{2} 2009$.

Oepke A., egeirō, w: Kittel G., Friedrich G. (red.), Grande Lessico del Nuovo Testamento, t. III, Brescia 1967, kol. 22-30.

Ostański P., Objawienie Jezusa Chrystusa. Praktyczny komentarz do Apokalipsy, Ząbki 2005.

Pedroli L., Dal fidanzamento alla nuzialità escatologica. La dimensione antropologia del rapporto tra Cristo e la Chiesa nell'Apocalisse, Assisi 2007.

Podeszwa P., Jezus jako Arcykapłan w świetle J 19,23 i Ap 1,13, w: D. Dziadosz (red.), Od Melchizedeka do Jezusa Arcykapłana. Biblia o kapłaństwie, Lublin 2010, s. 202-207.

Podeszwa P., Od inspiracji do interpretacji. Grafiki artystyczne w ilustrowanym wydaniu Biblii Poznańskiej, „Teologia i Człowiek” 27(2014)3, s. 159-171.

Podeszwa P., Paschalna pamięć o Jezusie. Studium egzegetyczno-teologiczne wyrażenia hē martyria Iēsoû w Apokalipsie św. Jana, Poznań 2011.

Popielewski W., Od „Siódmej pieczęci” I. Bergmana aż po „legion” S. Stewarta - czego laicka sztuka filmowa szuka w Apokalipsie św. Jana?, w: Biblia kodem kulturowym Europy, red. S. Szymik, Lublin 2013, s. 249-265.

Prigent P., L'Apocalypse de Saint Jean, Genève 2000.

Ravasi G., Apokalipsa, Kielce 2002.

Rigato M.-L., Giovanni: l'enigma il Presbitero il culto il Tempio la cristologia, Bologna 2007.

Rogozińska R., Apokalipsa według Grzegorza Bednarskiego. Eskalacja zła czy orędzie nadziei?, „Sacrum et Decorum” 3(2010), s. 95-114.

Segalla G., La memoria simbolica del Gesù terreno nel libro dell'Apocalisse, LA 50(2000), s. $115-141$.

Sieg F., „Podobny do Syna Człowieczego” (analiza porównawcza Ap 1,12-16; 19,11-16), STV 26(1988)1, s. 251-255.

Sieg F., Implikacje formuly samookreśleniowej Ap 1,17c.18 dla interpretacji Baranka w Ap 4-5, SS 8-9(2004-2005), s. 225-239. 
Sikora A.R., Archē, w Apokalipsie św. Jana, w : S. Bielecki, H. Ordon, H. Witczyk (red.), W posłudze Stowa Pańskiego. Księga pamiątkowa poświęcona ks. prof. dr. hab. Józefowi Kudasiewiczowi z okazji 70-lecia urodzin, Kielce 1997, s. 319-328.

Vanni U., L’Apocalisse. Ermeneutica, esegesi, teologia, Bologna 1991.

Wojciechowski M., Apokalipsa świętego Jana. Objawienie, a nie tajemnica, Częstochowa 2012.

Wojciechowski M., Zmartwychwstanie w Apokalipsie św. Jana, w: A. Paciorek, A. Tronina, P. Łabuda (red.), Zmartwychwstał prawdziwie, Tarnów 2010, s. 263-273. 